\title{
THE SOURCES OF WRITING BUSTAN AL-SALATIN BY NUR AL-DIN AL- RANIRI: A STUDY BASED ON BOOK I-BOOK IV
}

\author{
Norhayati Haji Hamzah*
}

\begin{abstract}
Bustan al-Salatin fi Dhikr al-Awwalin wa al-Akhirin (The Garden of the Kings on the Recollection of the Past and Present) (henceforth Bustan) is a masterpiece of Islamic history written by Nur al-Din alRaniri (cited hereafter al-Raniri) in the seventeenth century Aceh. It is the best-known work of al-Raniri on history and the biggest book written in the history of traditional Malay literature that consists of seven books with the total of 60 chapters. The large contents of Bustan comprise of universal history and a "mirror for rulers" covers the period from the creations of the world until the Malacca and Aceh Sultanates in the Malay World. Accordingly, numerous and different kinds of sources and references were used by al-Raniri in writing Bustan. Therefore, this article endeavours to analyze the sources in Book I-Book IV of Bustan. This research is a qualitative research that applies the technique of documentation in collecting data while inductive approach to content analysis was utilized for data analyzing. The main documents used were the two versions of the manuscript of Bustan (Raffles Malay 8 and UM 41). The finding indicates that al-Raniri used distinct types of authentic sources of Islamic history especially the Qur'an and hadith which is evident in the utilization of 167 Qur'anic verses and 216 hadith. Qur'anic verses were mainly used in the narration on the creation of the universe, while hadith communicated the stories of the caliphs and former kings' conduct.
\end{abstract}

Keywords: Nur Al-Din Al-Raniri, Bustan al-Salatin, Classical Malay Literature, Islamic History, Sources of writing

\section{Introduction}

Bustan al-Salatin was a distinguished historical work written by Nur al-Din al-Raniri (d. 1068 AH /1658 $\mathrm{AD}$ ) in the seventeenth century Aceh. It was written in 1638 by the order of Sultan Iskandar Thani of Aceh (1636-1641). Al-Raniri was a prominent scholar of Aceh who had authored 35 works that covered the fields of mysticism and theology ( 24 books), Islamic jurisprudence ( 3 books), history ( 6 books) and hadith ( 2 books). ${ }^{1}$ Apart from his works on the aforementioned fields, al-Raniri was a great historian as he was the first writer in the Malay-Indonesian World to initiate a new form of Malay historical writing and to introduce the concept of Islamic history in Bustan. ${ }^{2}$ He did not only pioneer the concept of universal history but also the concept of Islamic history that is clearly seen in the structure and the purpose of writing Bustan. Al-Raniri narrated the universal history chronologically, originating from the creation of the universe, the stories of the prophets and the former kings (the kings of ancient Greek, Rome, Egypt and Arabia), the Islamic caliphate and ended with the Malay Kings in Aceh and Pahang ${ }^{3}$ in the seventeenth century. As Bustan consists of 60 chapters (fasal), it became the largest work of alRaniri and the longest text written in the traditional Malay literature. It provides historical narratives concerning universal history starting from the creation of the world until the Sultanates of Pahang and

\footnotetext{
${ }^{*}$ Norhayati Haji Hamzah, Senior Lecturer, Department of Islamic History and Civilization, Academy of Islamic Studies, University of Malaya, Kuala Lumpur, Malaysia. Email: yati611@um.edu.my.

${ }^{1}$ Al-Raniri was born into a diaspora Hadhrami family of Hamid clan in Ranir in Gujerat. Based on his own statement in Book I of Bustan, alRaniri referred to himself as "Syeikh Nuruddin anak 'Ali Hasanji anak Muhammad, Hamid nama bangsanya, Ranir nama negerinya, dan Syafi'i mazhabnya..." (Nuruddin the son of 'Ali Hasanji, the son of Muhammad, Hamid was his clan, Ranir was the place he belonged to and Shafi ${ }^{i}$ was his mazhab (sect). Refer to Raffles Malay 8 (Bustan al-Salatin), p. 3; Raffles Malay 42 (Bustan al-Salatin), p. 3 \& UM 41 , p. 3. Al-Raniri's date of birth is unknown, but Azra and Amirul (2004) suggest that al-Raniri was born towards the end of the sixteenth century (C.A. Grinter (1979), Book IV of the Bustan us-Salatin by Nuruddin Ar-Raniri: A Study from the Manuscripts of a 17th Century Malay Work Written in North Sumatra, Doctoral thesis, University of London, United Kingdom), p. 8; Azyumardi Azra (2004), The Origins of Islamic Reformism in Southeast Asia, Australia: Allen \& Unwin, p. 54; Amirul Hadi (2004), Islam and State in Sumatra, Leiden: Brill Academic Publishers, p. 153.

${ }^{2}$ Azyumardi Azra (2004), The Origins of Islamic Reformism in Southeast Asia, p. 68; Muhammad Yusoff Hashim (1992), Pensejarahan Melayu: Kajian Tentang Tradisi Melayu Nusantara, Kuala Lumpur: Dewan Bahasa dan Pustaka, p. 234; Syed Muhammad Naquib Al-Attas (1972), Islam dalam Sejarah dan Kebudayaan Melayu, Kuala Lumpur: Penerbit Universiti Kebangsaan Malaysia, p. 47; Jelani Harun (2009), Bustan al-Salatin: A Malay Mirror for Rulers, Pulau Pinang: Penerbit Universiti Sains Malaysia, pp. 92-97.

${ }^{3}$ Aceh, located in the Northwest of Sumatra Island is one of the provinces in Indonesia. Meanwhile, Pahang is one of the states in Peninsular Malaysia.
} 
Aceh during the seventeenth century. ${ }^{4}$ Among the stories it narrated are the creation of the seven layers of heaven and the seven layers of earth, the history of the Prophets and the history of pious kings and pious saints of Allah. ${ }^{5}$

The background of al-Raniri and his oeuvres have been studied in a dedicated number previously. Most of them were authored by prominent scholars such as Tuuk (1866), Nieuwenhuijze (1948), Voorhoeve (1951, 1955, 1959), Drewes (1955), al-Attas (1966), T. Iskandar (1966, 1967, 1968), Daudy (1983), Azra (2004) and Jelani (1999, 2001, 2004, 2008, 2009). Their writings are vital and valuable but there was an element of fragmentation in these brilliant works as most of them were only engrossed in alRaniri's biography, the list of his works, his contribution to the field of mysticism and theology as well as his refutation against Wahdat al-Wujud/Wujudiyyah (The unity of being). ${ }^{6}$ Furthermore, specific studies on Bustan were carried out by a few scholars such as Wilkinson (1900), Winstedt (1920), Jones (1974), Grinter (1979), Linehan, W. (henceforth Linehan) (1933), Siti Hawa (1996), Jelani (1996, 1999, 2001, 2003, 2004, 2006, 2008, 2009, etc.) and Warmser (2012). A majority of these scholars such as Wilkinson, Siti Hawa and Jelani Harun and Jones published the contents of Bustan (Book II, Book III and Book IV). All the above studies largely discussed al-Raniri's biography and his works without diving into a specific study on the sources of writing Bustan. Therefore, the objective of this study is to analyze the sources in Book I-Book IV of Bustan, making it the first study of its kind at the moment of its publication.

\section{The Sources of Bustan Al-Salatin (Book I-Book IV)}

Categorically, the contents of Bustan can be diverged into two categories. Primarily, the historical element (the creation of the world and the history of the Prophets (the messengers of Allah), the endeavours and affairs of quondam kings as well as their longevity from the time of Sultan Kiyaumurthi to the time of our lord Sultan Iskandar Thani Alauddin Mughayat Syah Johan Berdaulat. Secondly, the element of the mirror for princess (didactic element). The didactic element cannot be seperated from the writing of Islamic history as the didactic itself is the fundamental principle in the understanding of Islamic history. It begins with history and finalizes with counsel to the reader. In other words, in Islam the didactic becomes part of history as history in Islam is the manifestation of the divine plan, beginning with the creation of Adam until the day after resurrection. Both elements (history and didactic) generally used Islamic sources except for the history of the Sultan of Melaka, Pahang and Aceh that are mainly based on the Malay local sources. Due to the large content of Bustan, variety of sources were utilized by al-Raniri, both primary and secondary sources such as the Qur'an, hadith, companions of the Prophet Muhammad (PBUH), Muslim historians as well as Muslim and non-Muslim scholars. However, this article will only elaborate on the Qur'an and hadith as both are the basic primary sources of Islam as below:

\section{Qur'an}

Qur'an as the main source of historical writing have been accepted by many Muslim historians such as al-Tabari (d. 310 AH/923 AD), al-Mas'udi (d. 345 AH/956 AD) and Ibn Khaldun (d. 808 AH/1406 $\mathrm{AD})^{7}$ due to the fact that it is rich with historical sources which contain the history of the creation of the universe, stories of the people of the past, history and biographies of the Prophets and individuals. ${ }^{8}$ In addition, the Qur'an also chronicles the accounts of past nations that disobeyed Allah and the punishments they suffered due to their attitudes. The purpose of these stories is to reveal the truth of Islam as the religion of Allah and to illustrate portent from the lessons of history. It is from the Qur'an that Muslims procured the postulations of the meaning of history, the purpose of studying history, the

\footnotetext{
${ }^{4}$ Siti Hawa Haji Salleh (ed.) (1992), Bustan al-Salatin, Kuala Lumpur: Dewan Bahasa dan Pustaka, p. xiv; Jelani Harun (1999), Nuruddin alRaniri's Bustan al-Salatin, Doctoral thesis, University of London, United Kingdom, p. 3.

${ }^{5}$ Raffles Malay 8 (Bustan al-Salatin) \& Raffles Malay 42 (Bustan al-Salatin).

${ }^{6}$ Azyumardi Azra (2004), The Origins of Islamic Reformism in Southeast Asia, Australia: Allen \& Unwin, pp. 104 \& 106.

${ }^{7}$ Al-Tabari, Abu Ja'far Muhammad ibn Jarir (1961), Ta'rikh al-Rusul wa-al-Muluk, Vol. 3, Misr: Dar al-Ma'arif, pp. 1, 2, 11, 14, 18 \& 20; Al-Mas'udi, Abu al-Hasan 'Ali b. al-Husayn (1973), Muruj al-Dhahab wa Ma'adin al-Jawahir, Vols. 1-2, Beirut: Dar Al-Andalus, pp. 38, 39, 40, 67, 71 \& 88; Ibn Khaldun, 'Abd al-Rahman ibn Muhammad (1961), Tarikh al-'Allamah Ibn Khaldun: Kitab al-'Ibar wa-Diwan alMubtada' wa-al-Khabar fi Ayyam al-'Arab wa al-'Ajam wa al-Barbar wa man 'asarahum min dhawi al-Sultan al-Akhbar, Bayrut: Maktabat

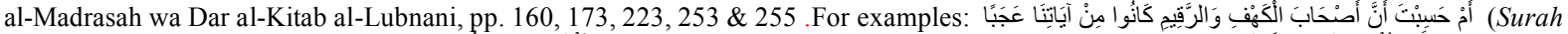

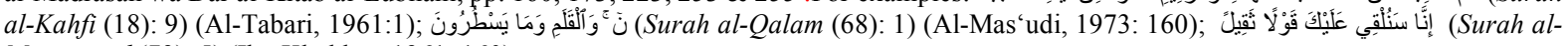
Muzzammil (73): 5) (Ibn Khaldun, 1961: 160)

${ }^{8}$ A. A. Duri (1983), The Rise of Historical Writing Among the Arabs, (Lawrence I. Conrad, Trans.), New Jersey, U.S.: Princeton University Press. (Original work published 1960), p. 20; Muhidin Mulalic (2012), A Survey of Early Muslim Historiography, Kuala Lumpur, Malaysia: A.S. Noorden, p. 166.
} 
admonitions and enlightenment of bygone history, universal history and so forth. Therefore, it cannot be denied that the Qur'an encourages humans to study history and provides mankind with the incentive to study history. ${ }^{9}$

The above explanation indicates the importance of the Qur'an as the main source of history in Muslim historiography. With the spread of Islam to many places in the world including the Malay world, the Qur'anic concept of history and the methodology of Muslim history writing were introduced to the Malays simultaneously with the coming of Islam. Al-Raniri as one of the scholars in the Malay world was also influenced by the Islamic concept of history and methodology including its sources. This is clearly seen in al-Raniri's sources for writing Bustan that are the Qur'an, hadith and reliable Muslim scholars.

Concerning the Qur'an as one of al-Raniri's sources in writing Bustan, below is the detailed elaboration on the Qur'anic verses found in Bustan. The purpose of evincing all the surah and verses used by alRaniri from Book I-Book IV is to indicate the importance of the Qur'an to al-Raniri as the basic source of Islamic knowledge including Islamic history and importantly, the Qur'an as the main source of alRaniri's writing. Therefore, al-Raniri made the Qur'an as his frame of history that is evident with the application of 167 Qur'anic verses in Book I - Book IV. In the researcher's opinion, al-Raniri's clear understanding of Islamic concept of history led him to make the Qur'an as one of his main sources for Bustan.

Moreover, al-Raniri employed Qur'anic verses to strengthen his narration on the creation of the universe, the history of the Prophets, the messenger of Allah and stories with didactic elements. For example, the Qur'an employs richly the stories of the Prophets such as the Prophet Adam, Nuh, Musa, Ibrahim, 'Isa, etc. Based on the stories of the Prophets and messengers of Allah in the Qur'an, al-Raniri applied similar subjects inside Bustan. Prior to al-Raniri, al-Tabari, al-Mas'udi and Ibn Khaldun also described the stories of the Prophets in their historical works. Below are some of the Qur'anic verses in Bustan relating to stories of the Prophets of Islam.

\section{The Prophet Adam}

"Maka adalah yang pertama segala anbia itu Nabi Allah Adam 'alayhi al-salam. Kata segala 'ulama, tatkala dikehendaki Allah Subhanahu wa Ta'ala menjadikan Nabi Allah Adam 'alayhi al-salam, maka ia berfirman seperti yang tersebut dalam Qur'an (Sad: 71):

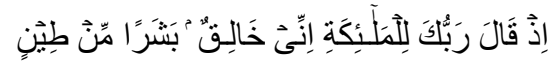

[Ertinya]: Dan tatkala berfirman Tuhanmu pada segala malaikat, "Bahawanya Aku hendak menjadikan insan daripada tanah." 10 Maka berfirman Allah Ta'ala kepada Jibril, "Hai Jibril, pergilah engkau ke bumi, ambil olehmu tanah dari segala bumi, Aku hendak menjadikan suatu kejadian daripadanya."

(The Prophet Adam was the first prophet on earth and once Allah decided to create Adam, he ordered Jibril, one of the angels to take some soil from the earth but the earth was reluctant of Jibril's request).

\section{The Prophet Nuh}

“...Maka segala kaumnya pun sangatlah berbuat durhaka. Maka Nabi Nuh 'alayhi alsalam pun berdatang sembah ke hadarat Allah Ta'ala, seperti firman Allah Ta'ala yang tersebut dalam Qur'an (Nuh: 26):”

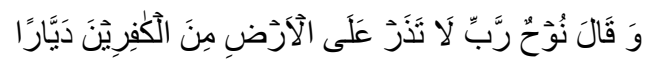

[Ertinya]: Ya Tuhanku, janganlah Kautinggalkan seorang jua pun di bumi daripada mendiami rumah mereka itu. ${ }^{11}$ Maka diperkenan Allah Ta'ala pintanya Nabi Nuh 'alayhi al-salam itu. Maka Nabi Allah Nuh pun dititahkan Allah Ta'ala berbuat sebuah bahtera.

\footnotetext{
${ }^{9}$ M.G. Rasul (1968), The Origin and Development of Muslim Historiography, Lahore, Pakistan: Sh. Muhammad Ashraf, p. 2.

${ }^{10}$ The verse means, "[So mention] when your Lord said to the angels, "Indeed, I am going to create a human being from clay."

${ }^{11}$ The verse means, "And Noah said: My Lord! Leave not one of the disbelievers in the land".
} 
Setelah sudah maka dititahkan Allah Ta'ala Nabi Nuh menaikkan anaknya Sam dan Ham dan Yafit serta segala isterinya dan daripada tiap-tiap jenis [binatang] datang sujud ke dalam bahtera itu. Dan adalah naik ke dalam bahtera itu enam orang, dan pada satu riwayat dualapan puluh orang laki-laki. Dan adalah ditinggalkan Nabi Allah Nuh anaknya yang bernama Yam daripada sebab ia kafir."

(UM 41:117-118)

(The subjects of Prophet Nuh extremely disobeyed Allah, therefore, the Prophet Nuh prayed to Allah to quell all of them. Allah then ordered him to build an ark and bring along his wives and every kind of animals into the ark. The son of the Prophet Nuh named Yam was left as he was an infidel).

Both examples show that al-Raniri selected verses of the Qur'an to support his argument on the accuracy of the facts of both Prophets. The utilization of Qur'anic verses is repeated in many places in Bustan. Therefore, it can be concluded that al-Raniri relied on the genuine source of Islam that is the Qur'an.

Table 1: List of Surahs and Verses in Bustan (Book I-IV)

\begin{tabular}{|c|c|c|c|}
\hline \multirow{2}{*}{$\begin{array}{c}\text { SOURCES } \\
\text { AL-QURAN }\end{array}$} & \multicolumn{3}{|c|}{ BOOK I } \\
\hline & FASAL & PAGE & VERSES \\
\hline & 1 & 6 & Al-Saff (61): 8 \\
\hline & 4 & 13 & Al-Haqqah (69):17 \\
\hline & 4 & 14 & Al-Mu'min/Al-Ghafir (40): 7 \\
\hline & 4 & 17 & Al-Hijr (15): 21 \\
\hline & 5 & 17 & Al-Baqarah (2): 255 \\
\hline & 7 & 19 & Al-Tahrim (66): 6 \\
\hline & 7 & 21 & Al-Najm (53): 5-7 \\
\hline & 7 & 21 & Al-Najm (53):13-18 \\
\hline & 8 & 26 & Al-Najm (53): 15-16 \\
\hline & 9 & 27 & Al-Rahman (55): 15 \\
\hline & 9 & 27 & Al-Kahfi (18): 50 \\
\hline & 11 & 31 & Al-Dhariyat (51): 47 \\
\hline & 11 & 31 & Hud (11): 7 \\
\hline & 11 & 31 & Al-Hadid (57): 4 \\
\hline & 11 & 31 & Yunus (10): 3 \\
\hline & 11 & 31 & Fussilat (41): 11-12 \\
\hline & 11 & 32 & Al-Nazi'at (79): 27-29 \\
\hline & 11 & 33 & Qaf (50): 38 \\
\hline & 11 & 34 & Al-Mulk (67): 3 \\
\hline & 12 & 37 & Al-Rahman (55): 46 \\
\hline & 12 & 37 & Al-Rahman (55): 62 \\
\hline & 12 & 39 & Al-Hadid (57):21 \\
\hline & 12 & 39 & Al-Kawthar (108):1 \\
\hline & 12 & 40 & Muhammad (47): 15 \\
\hline & 13 & 40 & Al-Rahman (55): 72 \\
\hline & 13 & 40 & Al-Rahman (55): 56 \\
\hline & 13 & 41 & Al-Rahman (55): 58 \\
\hline & 13 & 42 & Al-Rahman (55): 68 \\
\hline & 13 & 42 & Al-Waqi'ah (56): 27-34 \\
\hline & 13 & 43 & Al-Waqi'ah (56): 35-37 \\
\hline & 15 & 45 & Al-Saffat (37): 5 \\
\hline & 15 & 45 & Al-Takwir (81): 1 \\
\hline & 15 & 45 & Al-Nahl (16): 16 \\
\hline & 15 & 46 & Al-Anbiya' (21): 33 \\
\hline & 16 & 48 & Al-Saffat (7): 6-10 \\
\hline & 18 & 49 & Al-Nur (24): 43 \\
\hline & 21 & 50 & Al-Talaq (65): 12 \\
\hline
\end{tabular}


The Sources of Writing Bustan al-Salatin by Nur al-Din al-Raniri

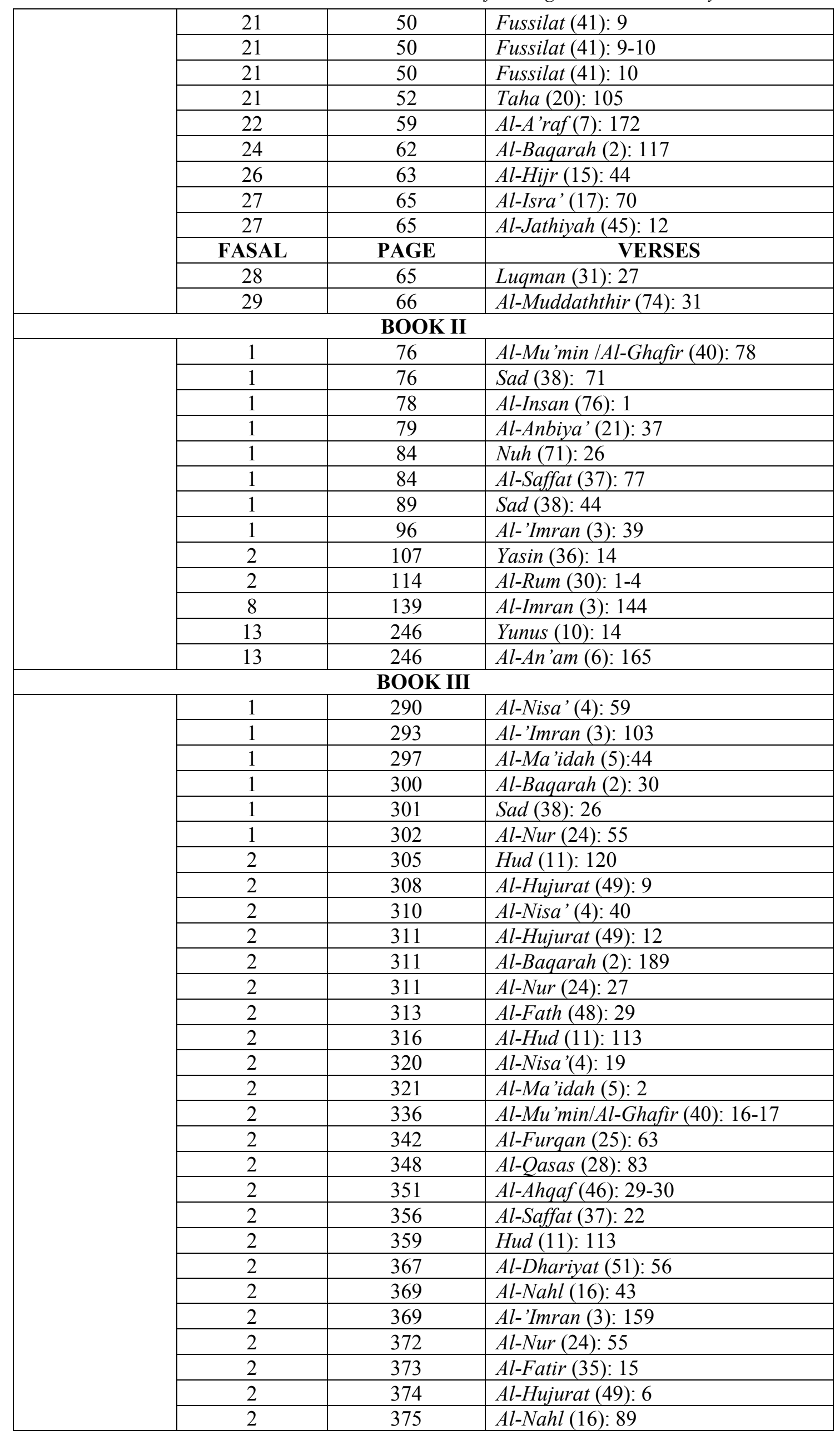




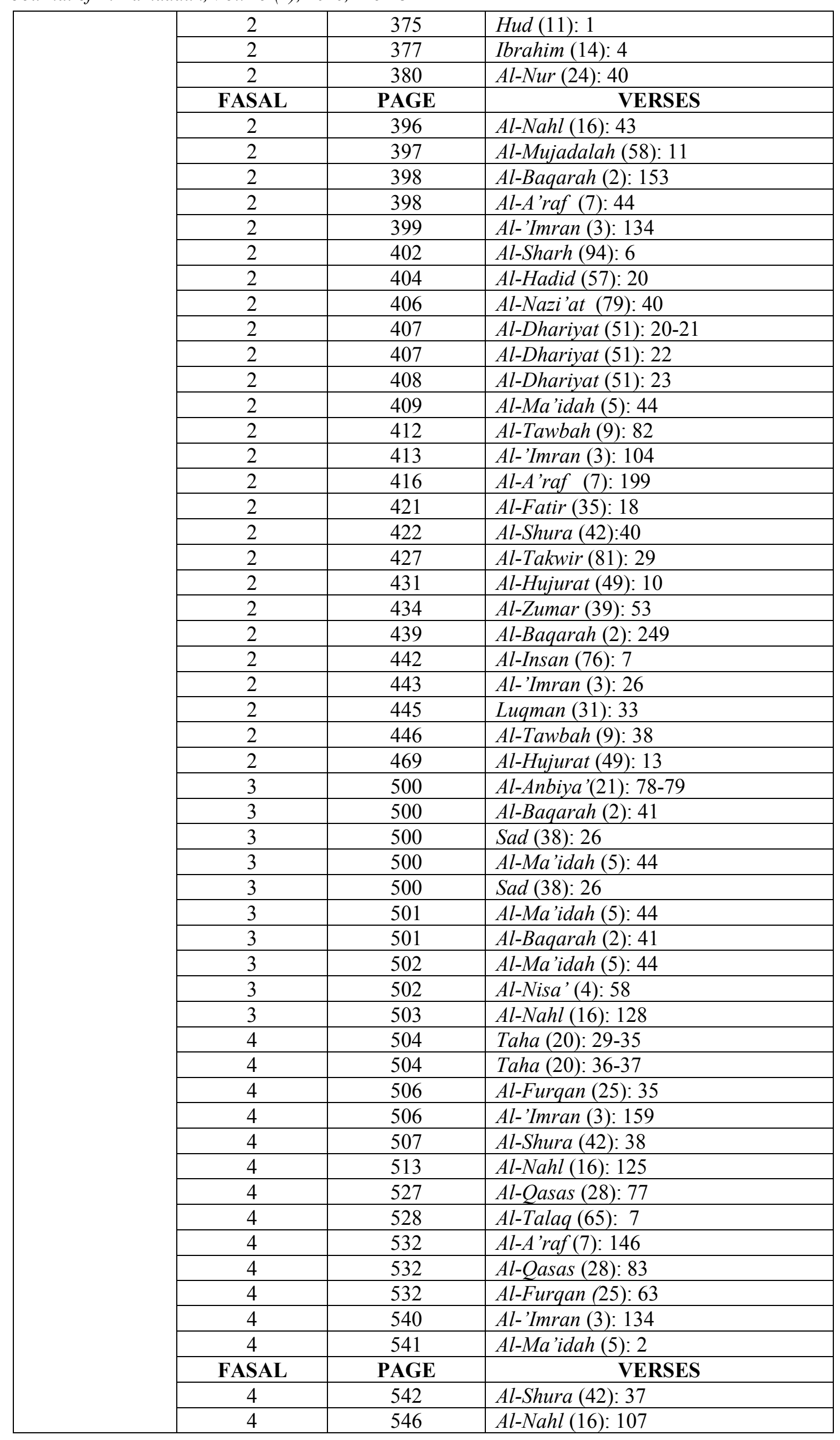


The Sources of Writing Bustan al-Salatin by Nur al-Din al-Raniri

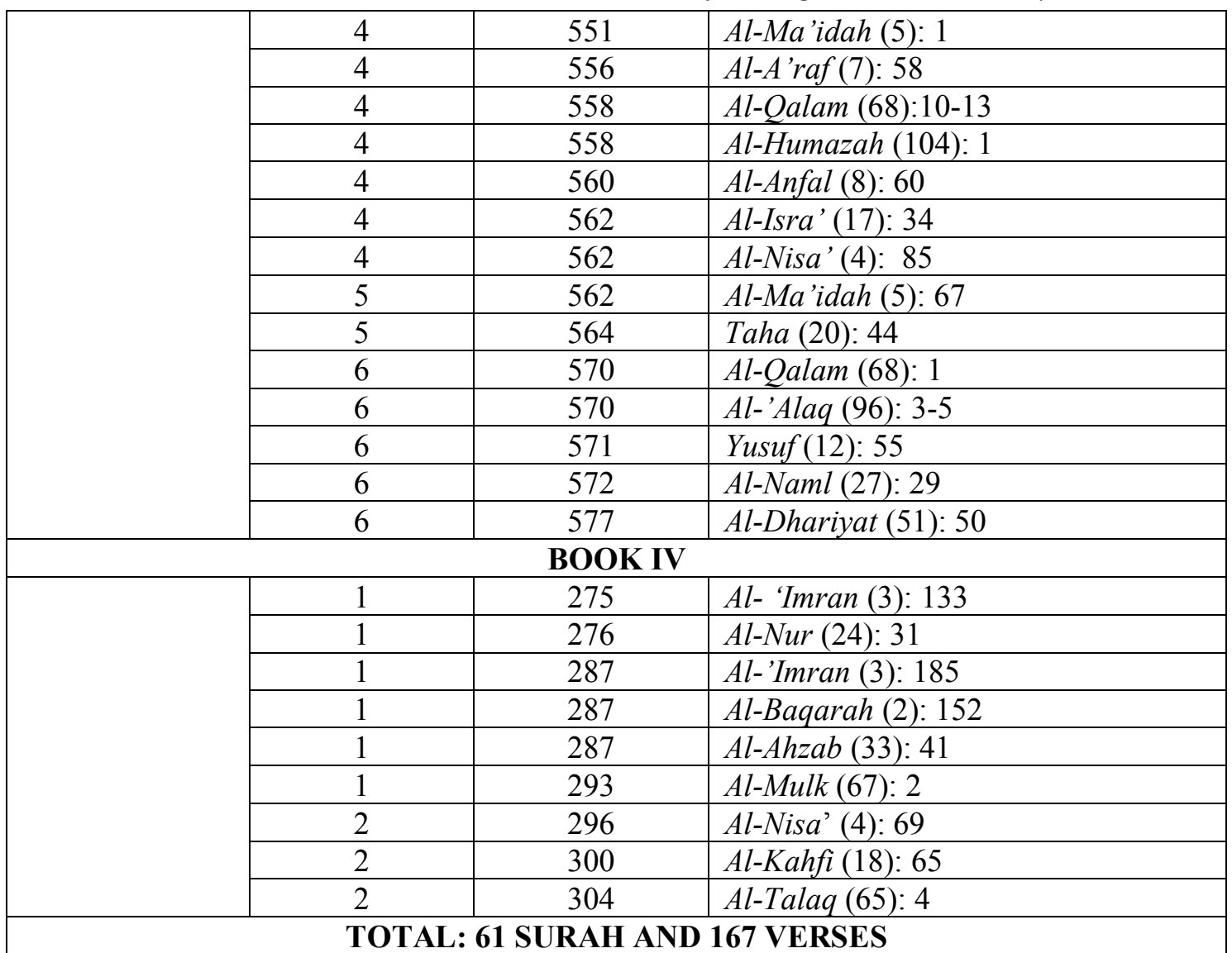

Sources: Book I, II \& IV are based on Raffles Malay 8, Book III from UM 41

Table 1 demonstrates the list of surahs and Qur'anic verses in Book I-Book IV of Bustan and their frequencies. Based on the analysis of the content of Bustan, there are at least 61 surahs and 167 verses utilized by al-Raniri. The monumental number of surahs and verses highlights al-Raniri's reliance on the Qur'an as one of his main sources. Book I (The Creation of the seven layers of heaven and the seven layers of earth including pertinent elements) contains 48 verses, Book II (bearing upon the beginning of the history of the Prophets and the messengers of Allah), 13 verses, Book III (pertaining to the beginning of the history of the Prophets and the messengers of Allah, including their duties, and encompasses the conduct of the caliphs and just kings including their duties, and also the qualities required of wise viziers and their conducts), 97 verses and Book IV (concerning the conduct of pious kings and pious saints of Allah) with 9 verses. Book I and Book III contain the highest number of Qur'anic verses that will be discussed below.

The 48 verses in Book I indicate that al-Raniri regarded the creation of the universe as an important historical fact as it is the starting point of the concept of Islamic universal history. In fact, there are a multitude of verses in the Qur'an that deals with the creation of the earth and heaven. ${ }^{12}$ Therefore, alRaniri selected 31 surahs (contain 48 verses) to strengthen his description on the creation of the universe. The 48 verses constitute the creation of the 'Arash of Allah (surah al-Haqqah (69):17), the angel (surah al-Tahrim (66): 6) and the seven layers of earth (surah Al-Dhariyat (51): 47; surah Hud (11): 7; surah Al-Hadid (57): 4; surah Yunus (10): 3; surah Fussilat (41):11-12; surah al-Nazi'at (79): 27-29 \& surah Qaf (50): 38). Examples of the verses are:

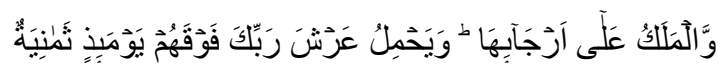

"And there will bear the Throne of your Lord above them, that Day, eight [of them]." (Surah al-Haqqah (69):17)

\footnotetext{
${ }^{12}$ For instances, surah al-Sajdah (32): 4; al-Kahfi (18): 51; al-Baqarah (2): 29; al-Nazi 'at (79): 29 \& al-Anbiya' (21): 30 (the creation of the heavens and earth), surah Fussilat (41): 9-12; al-Anbiya' (21):31; al-Nahl (16): 51 \& al-Naba (78) : 7 (the creation of mountains), surah alFurqan (25): 61; al-An'am (6): 97; al-Mulk (67): 5 \& al-Saffat (37): 6 (the creation of stars), surah al-Hijr (15) : 26, al-Sajdah (32): 7; alNisa' (4): 1 \& al-Zumar (39): 6 (the creation of man).
} 


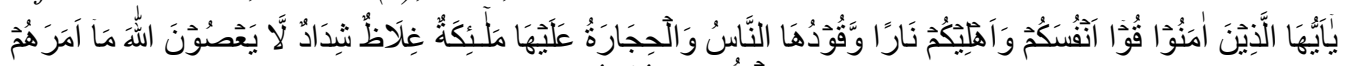

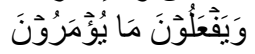

"O you who have believed, protect yourselves and your families from a Fire whose fuel is people and stones, over which are [appointed] angels, harsh and severe; they do not disobey Allah in what He commands them but do what they are commanded." (Surah al-Tahrim (66): 6)

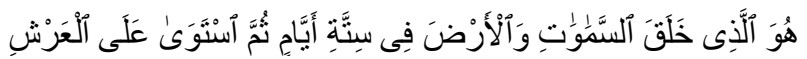

"It is He who created the heavens and earth in six days..." (Surah al-Hadid (57): 4)

Table 2: Frequencies of surahs used in Book I-IV of Bustan al-Salatin

\begin{tabular}{|c|c|c|}
\hline NO. & SURAH & FREQUENCY \\
\hline 1 & Al-An'am (6) & 1 \\
\hline 2 & Al-Anfal (8) & 1 \\
\hline 3 & Yusuf(12) & 1 \\
\hline 4 & Ibrahim (14) & 1 \\
\hline 5 & Al-Naml (27) & 1 \\
\hline 6 & Al-Rum (30) & 1 \\
\hline 7 & Al-Ahzab (33) & 1 \\
\hline 8 & Yasin (36) & 1 \\
\hline 9 & Al-Jathiyah (45) & 1 \\
\hline 10 & Al-Ahqaf (46) & 1 \\
\hline 11 & Muhammad (47) & 1 \\
\hline 12 & Al-Fath (48) & 1 \\
\hline 13 & Al-Mujadalah (58) & 1 \\
\hline 14 & Al-Saff (61) & 1 \\
\hline 15 & Al-Taghabun (64) & 1 \\
\hline 16 & Al-Tahrim (66) & 1 \\
\hline 17 & Al-Haqqah (69) & 1 \\
\hline 18 & Nuh (71) & 1 \\
\hline 19 & Al-Muddaththir (74) & 1 \\
\hline 20 & Al-Sharh (94) & 1 \\
\hline 21 & Al-'Alaq (96) & 1 \\
\hline 22 & Al-Humazah (104) & 1 \\
\hline 23 & Al-Kawthar (108) & 1 \\
\hline 24 & Qaf (50) & 1 \\
\hline 25 & Al-Zumar (39) & 1 \\
\hline 26 & Al-Tawbah (9) & 2 \\
\hline 27 & Yunus (10) & 2 \\
\hline 28 & Al-Hijr (15) & 2 \\
\hline 29 & Al-Isra' (17) & 2 \\
\hline 30 & Al-Luqman (31) & 2 \\
\hline 31 & Al-Kahfi (18) & 2 \\
\hline 32 & Al-Fatir (35) & 2 \\
\hline 33 & Al-Waqi'ah (56) & 2 \\
\hline 34 & Al-Mulk (67) & 2 \\
\hline 35 & Al-Qalam (68) & 2 \\
\hline 36 & Al-Insan (76) & 2 \\
\hline 37 & Al-Nazi'at (79) & 2 \\
\hline 38 & Al-Takwir (81) & 2 \\
\hline 39 & Al-Anbiya' (21) & 3 \\
\hline 40 & Al-Furqan (25) & 3 \\
\hline 41 & Al-Qasas (28) & 3 \\
\hline 42 & Al-Mu'min/Al-Ghafir (40) & 3 \\
\hline 43 & Al-Shura (42) & 3 \\
\hline 44 & Al-Najm (53) & 3 \\
\hline
\end{tabular}




\begin{tabular}{|c|l|c|}
\hline 45 & Al-Hadid (57) & 3 \\
\hline 46 & Al-Talaq (65) & 3 \\
\hline 47 & Taha (20) & 4 \\
\hline 48 & Al-Saffat (37) & 4 \\
\hline 49 & Fussilat (41) & 4 \\
\hline 50 & Al-A'raf (7) & 5 \\
\hline 51 & Hud (11) & 5 \\
\hline 52 & Sad (38) & 5 \\
\hline 53 & Al-Hujurat (49) & 5 \\
\hline 54 & Al-Nur (24) & 6 \\
\hline 55 & Al-Nisa' (4) & 6 \\
\hline 56 & Al-Dhariyat (51) & 7 \\
\hline 57 & Al-Rahman (55) & 7 \\
\hline 58 & Al-Nahl (16) & 8 \\
\hline 59 & Al-Ma'idah (5) & 9 \\
\hline 60 & Al-Baqarah (2) & 11 \\
\hline 61 & Al-'Imran (3) & $\mathbf{1 6 7}$ verses \\
\hline Total & \multicolumn{1}{|c|}{ surah } & 61 \\
\hline
\end{tabular}

Sources: Book I, II \& IV are based on Raffles Malay 8, Book III from UM 41

Table 2 shows the frequencies of surahs in Book 1-Book IV of Bustan. Surah al-'Imran composed the highest amount of surah exercised in Bustan (11 verses), followed by surah al-Ma'idah (9 verses), surah al-Baqarah (9 verses), surah al-Nahl (8 verses) and surah al-Rahman ( 7 verses). The significance of Qur'anic verses is apparent in al-Raniri's elaboration on the stories that contain didactic elements notably in Book III as the preponderance of the aforementioned surahs were used by al-Raniri in it. For example, surah al-Ma'idah (9 verses), surah al-'Imran (6 verses out of 11), surah al-Baqarah (6 verses out of 9) and surah al-Nahl (6 verses out of 8). In order to understand al-Raniri's purpose of using the highest frequency of surahs in Book III, there is a need to understand the meanings of these verses as below:

Table 3: Meaning of the Verses of Surah Al-Ma'idah in Book III

\begin{tabular}{|c|c|c|}
\hline $\begin{array}{c}\text { Surah Al- } \\
\text { Ma'idah (5) }\end{array}$ & Verses & Meaning \\
\hline & 1 & 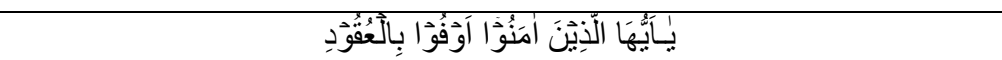 \\
\hline & & "O you who have believed, fulfill [all] contracts." \\
\hline & 2 (twice) & 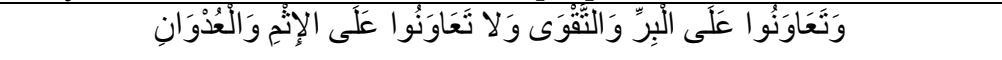 \\
\hline & & $\begin{array}{l}\text { "... And cooperate in righteousness and piety, but do not } \\
\text { cooperate in sin and aggression." }\end{array}$ \\
\hline & $\begin{array}{l}44 \text { (five } \\
\text { times) }\end{array}$ & 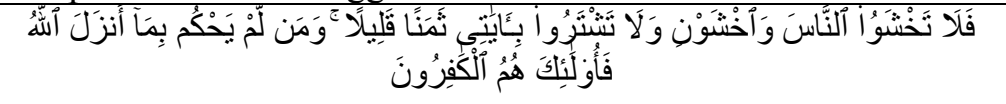 \\
\hline & & $\begin{array}{l}\text { "So do not fear the people but fear Me, and do not exchange My } \\
\text { verses for a small price. And whoever does not judge by what } \\
\text { Allah has revealed - then it is those who are the disbelievers." }\end{array}$ \\
\hline & 67 & 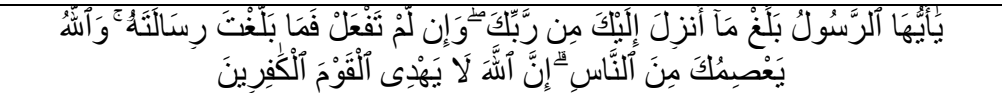 \\
\hline & & $\begin{array}{l}\text { "O Messenger, announce that which has been revealed to you } \\
\text { from your Lord, and if you do not, then you have not conveyed } \\
\text { His message. And Allah will protect you from the people." }\end{array}$ \\
\hline \multicolumn{2}{|c|}{ Ideas of these verses } & $\begin{array}{l}\text { Fear Allah and accept His revelation as well as enjoining good } \\
\text { and forbidding evil. }\end{array}$ \\
\hline
\end{tabular}


Table 4: Meaning of the Verses of Surah Al-'Imran in Book III

\begin{tabular}{|c|c|c|}
\hline $\begin{array}{l}\text { Surah Al-'Imran } \\
\text { (3) }\end{array}$ & Verses & Meaning \\
\hline & 26 & 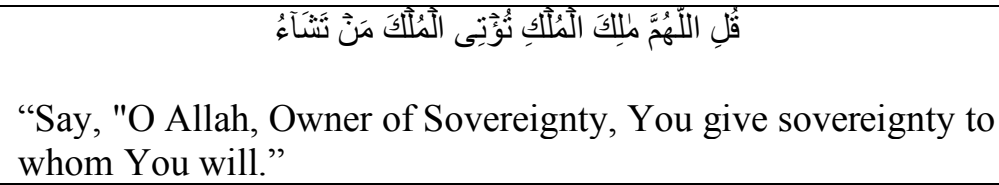 \\
\hline & 103 & 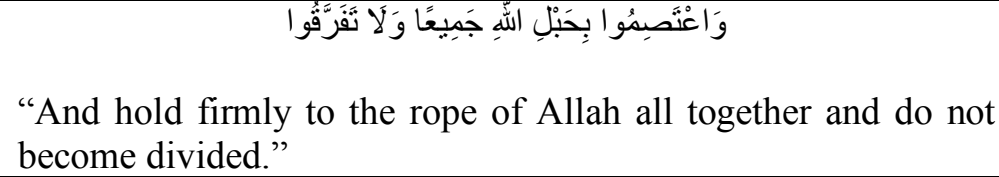 \\
\hline & 104 & 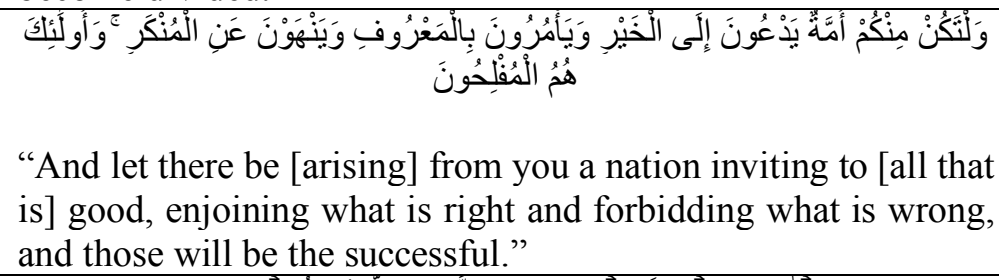 \\
\hline & 134 & 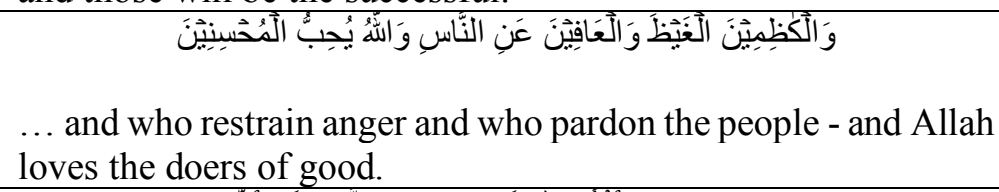 \\
\hline & $\begin{array}{c}159 \\
\text { (twice) }\end{array}$ & 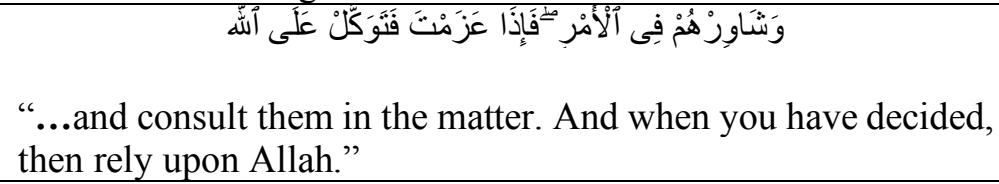 \\
\hline \multicolumn{2}{|l|}{ Ideas of these verses } & $\begin{array}{l}\text { Didactic element: Muslims must be united, enjoining right and } \\
\text { forbidding wrong, restrain anger and forgive others. }\end{array}$ \\
\hline
\end{tabular}

Table 5: Meaning of the verses of Surah Al-Baqarah in Book III

\begin{tabular}{|c|c|c|}
\hline Surah Al- & Verses & Meaning \\
\hline & 30 & 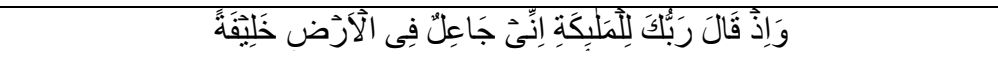 \\
\hline & & $\begin{array}{l}\text { "And [mention, O Muhammad], when your Lord said to the } \\
\text { angels, "Indeed, I will make upon the earth a successive } \\
\text { authority." }\end{array}$ \\
\hline & $\begin{array}{c}41 \\
\text { (twice) }\end{array}$ & 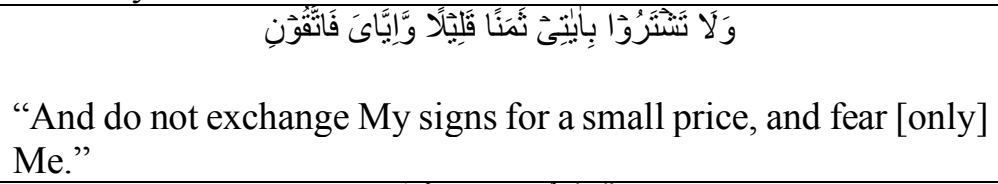 \\
\hline & 189 & 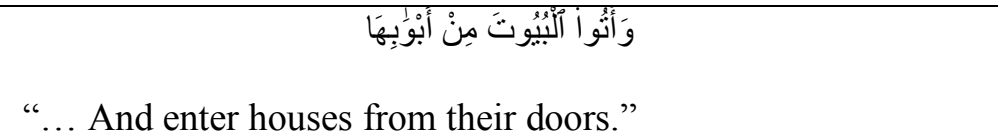 \\
\hline & 153 & 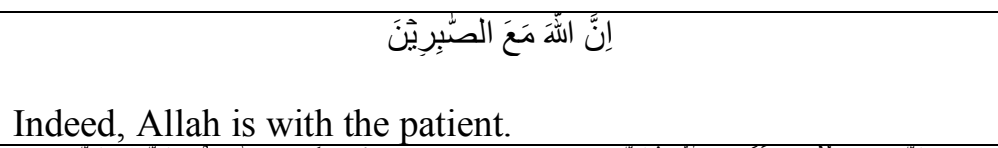 \\
\hline & 249 & 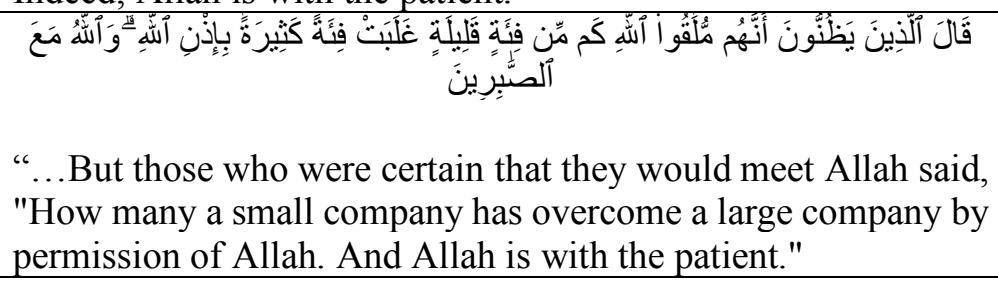 \\
\hline \multicolumn{2}{|c|}{ Ideas of these verses } & $\begin{array}{l}\text { Allah is the most powerful who created mankind as caliphs of } \\
\text { Allah on earth, thus mankind should fear Allah as to Him human } \\
\text { beings will return. }\end{array}$ \\
\hline
\end{tabular}


Table 6: Meaning of the Verses of Surah Al-Nahl in Book III

\begin{tabular}{|c|c|c|}
\hline Surah Al-Nahl & Verses & Meaning \\
\hline & $\begin{array}{c}43 \\
\text { (twice) }\end{array}$ & 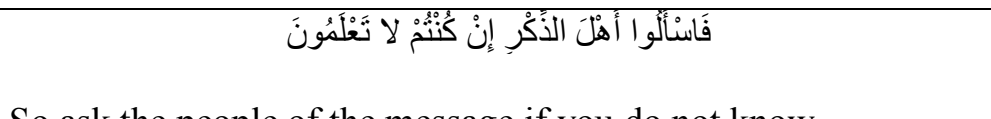 \\
\hline & 89 & 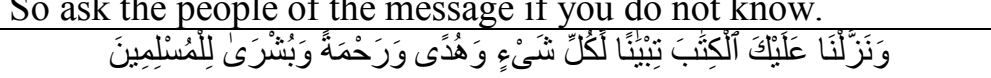 \\
\hline & & $\begin{array}{l}\text { And We have sent down to you the Book as clarification for all } \\
\text { things and as guidance and mercy and good tidings for the } \\
\text { Muslims. }\end{array}$ \\
\hline & 107 & 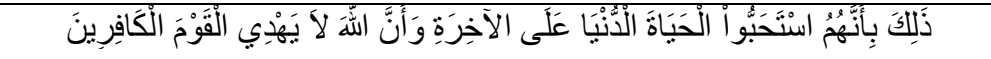 \\
\hline & & $\begin{array}{l}\text { That is because they preferred the worldly life over the Hereafter } \\
\text { and that Allah does not guide the disbelieving people. }\end{array}$ \\
\hline & 125 & 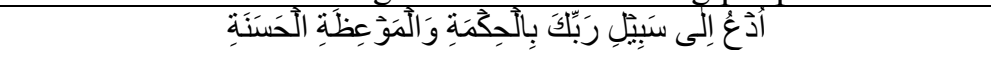 \\
\hline & & $\begin{array}{l}\text { Invite to the way of your Lord with wisdom and good } \\
\text { instruction. }\end{array}$ \\
\hline & 128 & $\begin{array}{l}\text { Indeed, Allah is with those who fear Him and those who are } \\
\text { doers of good. }\end{array}$ \\
\hline \multicolumn{2}{|c|}{ Ideas of these verses } & $\begin{array}{l}\text { Didactic element: Fear Allah and follow the teaching of the } \\
\text { Qur'an, inquire knowledge from knowledgeable people, invite } \\
\text { people to the way of Allah with wisdom, perform good deeds } \\
\text { and prioritize the hereafter. }\end{array}$ \\
\hline
\end{tabular}

Sources: Book I, II \& IV are based on Raffles Malay 8, Book III from UM 41

Tables 3-6 demonstrate the meaning of the selected verses from surahs al-Baqarah, al-'Imran, alMa'idah and al-Nahl. By categorically using the meanings of the verses and surahs as a foundation, it can be conclusively derived that Allah is the most powerful, such that mankind should fear Him and follow His revelations. The obligation to fear Allah has been repeated five times in surah al-Ma'idah and was mentioned once in surah al-Nahl. Thus, the above surahs and verses are parallel to al-Raniri's concept of tawhid in Bustan.

It is also noteworthy that almost every surah mentioned above contained didactic elements and for this reason they are applied in Book III of Bustan. The reasoning for this structural choice is that Book III is the specific chapter of Bustan that pertains to didactic. Didactic is the principle of understanding Islamic history, as the main purpose of history in Islam is to remind humanity of the transgressions of the past nations so that they take 'ibrah (lesson) from the past in order to live in accordance to the will of Allah. Therefore, al-Raniri in Book III provides advice to his readers to submit themselves to Allah, in correspondence to his propogative summon and willful guidance of the correct way to the Yawm alAkhirah where mankind will return to Allah.

In achieving his purpose of writing Bustan, al-Raniri narrates exceedingly of didactic stories for instance the stories of the Prophet Sulaiman, caliph al-Ma'mun and King Nushirwan supported by relevant Qur'anic verses. ${ }^{13}$ The verses in Table 3-Table 6 significantly contain didactic elements that guide mankind to moral actions such as enjoining right and forbidding wrong, invite people to the way of Allah with wisdom, patience, forgiveness, and the veritable accentuation of the hereafter over worldly life. Apart from that, these verses also indicate that morality is fundamental in Islam and that morality is the framework of Islamic history as emphasized by al-Raniri in Bustan. For example, the concept of justice where al-Raniri advised the kings to be just in his descriptions of virtuous kings such as the stories of 'Umar al-Khattab, Harun al-Rashid and 'Umar b. 'Abdul Aziz."

\footnotetext{
${ }^{13}$ Raffles Malay 8 (Bustan al-Salatin), pp. 306, $421 \& 456$.

${ }^{14}$ Raffles Malay 8 (Bustan al-Salatin), pp. 309-337; 339-351 \& 352-417.
} 
It can be stated that the Qur'an is one of the main sources used by al-Raniri in writing Bustan. The Qur'anic verses from Book I-Book IV convey al-Raniri's concept of Islamic history in which history is the manifestation of a divine plan where Allah is the only God and the creator of the universe. Therefore, submission to Allah is the main purpose of history in Islam. In Bustan (Book I-Book IV), al-Raniri begins with the description of the creation of the universe and mankind, the history of mankind on earth and ends with didactic stories that serve as guidance to the readers to submit themselves to Allah. All these subjects were described in the Qur'an and al-Raniri included them in Bustan along with the relevant Qur'anic verses. Therefore, based on the above explanation, it is apparent that al-Raniri's concept of Islamic history in Bustan parallels the content and purpose of Qur'an that clearly indicate that Bustan is indeed a book of Islamic history.

\section{Hadith - Tradition of the Prophet Muhammad (PBUH)}

Besides Qur'an, hadith was another historical source that al-Raniri relied on due to the fact that hadith served as the main source of Islamic history. Hadith contain many historical descriptions concerning the Prophet Muhammad (PBUH) and his companions. The usage of hadith in historical writing was utilized by early Muslim historians such as 'Urwah b. al-Zubair b. al-Awwam, ${ }^{15}$ Muhammad b. Shihab al-Zuhri, ${ }^{16}$ al-Baladhuri, ${ }^{17}$ al-Tabari, al-Mas'udi and Ibn Khaldun. For example, al-Tabari used a substantial amount of hadith in Ta'rikh al-Rusul wa al-Muluk. ${ }^{18} \mathrm{He}$ included hadith in his description, namely the revelation to the Prophet Muhammad (PBUH), the biography of the Prophet and his life as well as the maghazi (the military expedition of the Prophet). Similar to al-Tabari, al-Mas'udi also used hadith unstintingly in Muruj al-Dhahab that touched on the Khulafa al-Rashidin and the caliphate of Hasan b. 'Ali r.a. ${ }^{19}$ Last but not least, Ibn Khaldun also followed the trend of his counterparts by using hadith profusely in many parts of his work. ${ }^{20}$ For example, in Chapter III (On dynasties, royal authority, the caliphate, government ranks, and all relevant areas). ${ }^{21}$ Therefore, al-Raniri was influenced by the historical methodology of the early Muslim historians mentioned above which is clearly illustrated in his selection of the number of hadith in Bustan as the following.

Table 7: Number of Hadith in Bustan al-Salatin (Book I-IV)
\begin{tabular}{|c|c|}
\hline FASAL & $\begin{array}{c}\text { TOTAL NUMBER OF } \\
\text { HADITH }\end{array}$ \\
\hline \multicolumn{2}{|c|}{ BOOK I } \\
\hline 1 & 12 \\
\hline 2 & - \\
\hline 3 & - \\
\hline 4 & 1 \\
\hline 5 & - \\
\hline 6 & 2 \\
\hline 7 & - \\
\hline
\end{tabular}

\footnotetext{
15 'Urwah b. al-Zubair b. al-Awwam (d. 94 AH/724 AD) is a prominent scholar of hadith, jurist and historian. He was the pioneer of Muslim historiography and was among the earliest Muslim historians who wrote on sirah (biography of the Prophet Muhammad (p. b.u.h.) and maghazi. Refer to Nisar Ahmed Faruqi (1979), Early Muslim Historiography: A Study of Early Transmitters of Arab History from the Rise of Islam up to the end of Umayyad Period (612-750 A.D.), Delhi, India: Idarah-i Adabiyat-i Delli, p. 224; A.A. Duri (1983), The Rise of Historical Writing Among the Arabs, p. 25; Arba'iyah Mohd Noor (2002), Ilmu Sejarah dan Pensejarahan, Kuala Lumpur, Malaysia: Dewan Bahasa dan Pustaka, p. 182.

${ }^{16}$ His full name is Abu Bakr Muhammad b. Muslim b.'Ubaidullah b. 'Abdullah b. Shihab al-Zuhri (d. 124 AH/741 AD) (Muhd. Yusof Ibrahim and Mahayuddin (1988), Sejarawan dan Pensejarahan, Kuala Lumpur, Malaysia: Dewan Bahasa dan Pustaka, p. 120; Azra (2002), Historiografi Islam Kontemporer (Idris Taha, Ed.), Jakarta, Indonesia: Penerbit PT Gramedia Pustaka Utama, p. 34. Similar to 'Urwah, alZuhri is also a well-known scholar of hadith and among the earliest and famous writers of maghazi (M.G. Rasul (1968), The Origin and Development of Muslim Historiography, p. 13). His well-known work is al-Maghazi that contains the history of the prophets staring from the Prophet 'Adam until the period of the Prophet Muhammad (PBUH). Refer to Muhd. Yusof Ibrahim and Mahayuddin Haji Yahaya (1988), Sejarawan dan Pensejarahan, p. 122; Arba'iyah Mohd Noor (2002), Ilmu Sejarah dan Pensejarahan, p. 185.

${ }^{17}$ Ahmad b. Yahya b. Jabir al-Baladhuri (d.279 AH/892 AD) known as al-Baladhuri was one of the greatest Muslim historians in the third century of Hijra. M.G. Rasul (1968), The Origin and Development of Muslim Historiography, p. 23; Mulalic (2012), A Survey of Early Muslim Historiography, p. 119. His prominent works on history are Futuh al-Buldan (Conquests of the Provinces) and Ansab al-Ashraf (Genealogies of the Notables) (A.A. Duri (1983), The Rise of Historical Writing Among the Arabs, p. 61). Futuh al-Buldan contains the maghazi of the Prophet and the description on the opening of Syria, the Jazira, Armenia, Egypt, Iraq and others to Islam (M.G. Rasul (1968), The Origin and Development of Muslim Historiography, p. 22; Mulalic (2012), A Survey of Early Muslim Historiography, p. 122). Meanwhile, according to al-Duri, "Ansab al-Ashraf is a general work on Islamic history within a genealogical framework." (A.A. Duri (1983), The Rise of Historical Writing Among the Arabs, p. 62.

${ }_{18}$ Al-Tabari (1961), Ta'rikh al-Rusul wa-al-Muluk, pp. 19, 20, 124, 128, 132, 148, 217, 236, 286, 291, 298, 623, 633, etc.).

${ }^{19}$ Al-Mas'udi (1973), Muruj al-Dhahab, pp. 73, 150, 263, 294, 322, 344, 363, 422, 427, etc.

${ }^{20}$ Ibn Khaldun (1961), Tarikh al-'Allamah Ibn Khaldun, pp. 159, 160, 162,165, 175, 217, 235, 237, 249, 338, etc.

${ }^{21}$ Rosenthal, Franz (1967), Muslim Historiography, $2^{\text {nd }}$ Ed., Leiden, Netherlands: E.J. Brill, pp. 123, 127,153 \& 177.
} 


\begin{tabular}{|c|c|}
\hline 8 & 2 \\
\hline 9 & - \\
\hline 10 & - \\
\hline 11 & 3 \\
\hline 12 & 1 \\
\hline 13 & 4 \\
\hline 14 & - \\
\hline 15 & - \\
\hline 16 & - \\
\hline 17 & - \\
\hline 18 & - \\
\hline 19 & 1 \\
\hline 20 & 1 \\
\hline 21 & 2 \\
\hline 22 & 5 \\
\hline 23 & 1 \\
\hline 24 & - \\
\hline 25 & - \\
\hline 26 & - \\
\hline 27 & - \\
\hline 28 & - \\
\hline 29 & 2 \\
\hline 30 & 1 \\
\hline \multicolumn{2}{|c|}{ BOOK II } \\
\hline 1 & 2 \\
\hline 2 & - \\
\hline FASAL & $\begin{array}{c}\text { TOTAL NUMBER OF } \\
\text { HADITH }\end{array}$ \\
\hline 3 & - \\
\hline 4 & - \\
\hline 5 & - \\
\hline 6 & - \\
\hline 7 & - \\
\hline 8 & 6 \\
\hline 9 & - \\
\hline 10 & 1 \\
\hline 11 & - \\
\hline 12 & - \\
\hline 13 & 2 \\
\hline \multicolumn{2}{|c|}{ BOOK III } \\
\hline 1 & 23 \\
\hline 2 & 64 \\
\hline 3 & 9 \\
\hline 4 & 43 \\
\hline 5 & 1 \\
\hline 6 & 3 \\
\hline \multicolumn{2}{|c|}{ BOOK IV } \\
\hline 1 & 12 \\
\hline 2 & 12 \\
\hline TOTAL & 216 HADITH \\
\hline
\end{tabular}

Sources: Book I, II \& IV are based on Raffles Malay 8, Book III from UM 41

Table 7 demonstrates the number of hadith used by al-Raniri in Bustan (Book I-Book IV) that is 216 hadith. The big number of hadith suggests al-Raniri's reliance on hadith which is the second source of Islam and hadith was closely related to the discipline of Islamic history. Based on the table, Book I consists of 38 hadith, Book II with 11 hadith, Book III contains 143 hadith and Book IV with 24 hadith. 
Book III occupies the highest amount of hadith followed by Book I. The importance of hadith is evident in al-Raniri's elaboration on didactic elements in Book III. For Book I, majority of hadith were utilized in fasal 1(the creation of Nur Muhammad (the Light of Muhammad) (12 hadith) followed by fasal 22 (Chapter on the creation of the Ka 'bah) (5 hadith) and fasal 13 (Chapter on the creation of Nymphs) (4 hadith). For instance, hadith concerning the creation of Nur Muhammad and the Ka'bah:

Dan seperti hadis yang diceriterakan oleh Jabir radiya Allahu 'anhu: Inna Allah khalaqa ruh al-Anbiy sallāhu 'alayhi wa sallam, min dhatihi wa khalaqa al-'Alim bi asarihi min ruh Muhammad Nabi sallā Allāh 'alayhi wa sallam. Ertinya: Bahawasanya Allah Ta'ala menjadikan nyawa Muhammad daripada cahaya kudrat Zat-Nya, sallā Allāh 'alayhi wa sallam dan dijadikan sekalian alam ini daripada nyawa Muhammad.

(Raffles Malay 8: 6)

(According to Jabir r.a., Allah created the soul of the Prophet Muhammad from His (Allah) Essence dan the universe is created from this soul).

Kata Ibn 'Abbas radiya Allahu 'anhuma, tatkala diturunkan Allah Ta'ala Nabi Adam ke bumi, maka firman Allah akan dia, demikian bunyinya: Hai Adam, perbuat olehmu suatu rumah istana Aku. Maka Nabi Allah Adam pun berbuat Ka'bah Allah. Setelah itu maka Nabi Allah Adam pun rindu akan syurga, maka diturunkan Allah Ta'ala dari dalam syurga Hajar al-Aswad, lalu didakapnya supaya berjinak-jinakan ia dengan dia, seperti sabda Nabi sallā Allāh 'alayhi wa sallam: Nazala Hajar al-Aswad min al-Jannah wahuwa ashad bayadan min al-laban fasawwadathu khataya bani Adam, wama sa'aqati ahl al-Shirk wa lawla dhalika ma massahu dhu'ahati ila bari. Ertinya: Turun Hajar al-Aswad itu dari syurga itu dari dalam syurga, dan ada iaitu tersangat putih daripada air susu, dan jadi hitam ia kerana dosa segala manusia dan kerana dikucup segala kafir akan dia, dan jikalau tiada demikian itu nescaya sembuh segala orang yang berpenyakit.

(Raffles Malay 8: 56)

(According to Ibn 'Abbas r.a., Allah commanded the Prophet Adam to build Allah a palace. Consequently, the Prophet Adam built Allah's Ka'bah. When the Prophet Adam missed paradise, Allah sent to him Hajar al-Aswad from heaven. The Hajar al-Aswad was whiter than milk, it became black due to the sin of mankind and because of the disbelievers' kiss. If not because of that, all sickness would have recovered).

Meanwhile, fasal 8 of Book II (regarding the Birth of our Prophet Muhammad, the Messenger of Allah, may God bless him and grant him peace, and his ancestry) shows the highest number of hadith (6 hadith) used by al-Raniri. The reason is that the Prophet Muhammad (PBUH) is a prominent figure in Islamic history. Islamic history is closely related to the Prophet, owing to the fact that Islamic history begins with the advent of Islam and the appointment of the Prophet as the messenger of Allah. Furthermore, the Prophet also emboldens historical awareness among the Muslims which is evident in the development of sirah, maghazi and hadith. Therefore, hadith becomes the second main source of Islamic history besides the Qur'an. Al-Raniri's awareness on the importance of hadith in Islamic history propelled him to include numerous hadith in Bustan. Al-Raniri used hadith to report of the Prophet's sickness:

Dan pada hijrah itu (Hijrah kesebelas), Nabi sallā Allah 'alayhi wa sallam sakit pada hari kedua lapan hari bulan safar...Maka tatkala sangatlah Nabi Allah sakit, maka tiada dapat Nabi Allah sembahyang berjemaah. Kelakian maka sabda Nabi Allah kepada segala sahabat, demikian bunyinya, Murru Aba Bakri falyusalli bi al-Nas. Ertinya: Suruh kamu akan Abu Bakar jadi imam segala manusia... Hatta maka sakit Nabi Allah pun bertambahtambahlah. Arakian maka sabda Nabi Allah sallā Allāh 'alayhi wa sallam, Atuni bidawatin wa qirtas aktubu lakum kitaban la takhtalifu ba'dahu. Ertinya: Berilah oleh kamu akan daku dakwat dan kertas, aku surati akan dikau dengan surat supaya jangan kamu berbantah-bantah kemudiannya.

(Raffles Malay 8: 135)

(In the year eleven of Hijrah, the Prophet Muhammad (PBUH) fell sick to the extent that he could not lead the prayer. Therefore, the Prophet asked Abu Bakar to lead the prayer. Later, when the Prophet's illness became worse, he asked his companions to bring for him ink and paper to enable him to write a letter for them so that they will not argue later). 
Moreover, Book III, fasals 1 (23 hadith), fasals 2 (64 hadith) and fasals 4 (39 hadith) contain the highest number of hadith compared to the rest of the chapters with the total number of 126 out of 143 . Chapter 1 deals with the appointment of kings and their followers along with their duties (23 hadith), fasal 2 governs the conduct of the caliphs and kings of former times (64 hadith) and fasal 4 unveils the appointment of viziers and captains in collaboration with their duties (39 hadith). As mentioned before, al-Raniri was determined to guide his readers of the correct path to Allah. Therefore, he emphasized on the didactic elements in Bustan. As chapter III enumerated the conduct of the caliphs and just kings ergo explicated their duties, the qualities required of wise viziers and their conducts, it was resolved by al-Raniri to amplify his usage of hadith as a measure to indurate his description of the didactic elements. That is the reason why Book III has the highest amount of hadith. Below is an example of a hadith in the mentioned chapter of Book III:

Fasal 1

Kata Anas ibn Malik radiya Allahu 'anhu, ia mendengar daripada Nabi sallā Allāh 'alayhi wa sallam: Isma'u wa ati'u walaw ta'mara 'alaykum 'abdun habshiyyan. Ertinya: Dengar oleh kamu kata raja kamu dan ikut oleh kamu akan dia jikalau ada ia sahaya Habsyi sekalipun. ${ }^{22}$

(UM 41: 292)

(Anas ibn Malik radiya Allahu 'anhu heard the Prophet (PBUH) said: Listen to your king and follow him even if he was a Habsyi ${ }^{23}$ ).

Seperti sabda Nabi sallā Allāh 'alayhi wa sallam: 'Ala al-amara al-Muslim al-Sam'u wa al-Ta'ah fima ahabba au kariha illa an yu'mara bima'siyatin, fain amira bi ma'siyatin fala sam'a wala ta'ah. Ertinya: Fardu atas segala orang yang Islam mendengar kata rajanya dan berbuat bakti akan dia serta mengikut barang suruhannya, pada barang kesukaan atau kebajikan, melainkan jika disuruhnya berbuat derhaka kepada Allah Ta'ala, maka jangan didengarkan dan jangan ia mengikut suruhnya. ${ }^{24}$

(UM 41: 296)

(The Prophet (PBUH) says: It is obligatory for Muslims to obey their kings and to serve them on their needs and well-being except for disobedience to Allah).

\section{Fasal 2}

Seperti sabda Nabi sallā Allāh 'alayhi wa sallam: Al-Muslim akhu al-Muslim la yazlimuhu wa la yuslimuhu wa man kana fi hajati akhihi kana Allahu fi hajatihi. Ertinya: Yang Islam itu saudara samanya Islam, maka jangan kamu aniaya akan dia dan jangan kamu binasakan akan dia. Maka barangsiapa meluluskan kehendak saudaranya adalah Allah Ta'ala meluluskan kehendaknya. ${ }^{25}$

(UM 41: 346)

(The Prophet (PBUH) says: Muslims are brothers in Islam, therefore, they should not oppress and destroy each other. Those who fulfill the need of his brother, Allah will fulfill his need).

Seperti sabda Nabi sallā Allāh 'alayhi wa sallam: Kada al-Halim an yakuna bunyan. Ertinya: Yang menahan marah itu terhampir-hampir jua ia kepada martabat Nabi.

(The Prophet (PBUH) says: The rank of those whose refrain from anger is close to the rank of the Prophet).

Seperti sabda Nabi sallā Allāh 'alayhi wa sallam: An al-Muluk al-'Adalah la ta'kulu al'Ard ajsadahum. Ertinya: Bahawasanya segala raja-raja yang adil itu tiada dimakan bumi tubuh mereka itu.

(The Prophet (PBUH) says: The remains of just kings were imperishable).

\footnotetext{
${ }^{22}$ Sahih al-Bukhari, vol. 9, Book 89, no. 256.

${ }^{23}$ Habasyi refers to the Abbyssinian or the Euthiopian.

${ }^{24}$ Sahih al-Bukhari, vol. 9, Book 89, no. 258.

${ }^{25}$ Sahih al-Bukhari, vol. 3, Book 43, no. 622. A hadith narrated by 'Abdullah bin 'Umar r.a.
} 
$\underline{\text { Fasal } 3}$

Seperti sabda Nabi sallā Allāh 'alayhi wa sallam: Ma min qaum ya'malu fahum bi alma'asi, thumma yaqdiru 'ala an yughfiru thumma la yughfiru li asbabihim Allah bi 'iqabatin ilayhim. Ertinya: Tiada jua suatu kaum diperbuat dalam mereka itu perbuatan derhaka maka kuasa mereka itu, maka tiada ditegahkannya mereka itu, maka hampir diturunkan Allah Ta'ala atas mereka itu seksa-Nya dahulu daripada mati mereka itu.

(UM 41: 511)

(The Prophet (PBUH) said: The nations that committed misdeeds and they do not use their power to forbid it, hence Allah nearly brought down His punishment on them before they died).

Seperti sabda Nabi sallā Allāh 'alayhi wa sallam: Raksu al-'Akl ba'da lika yana basiru mudrati al-Nas wa ahl ma'rufuhum ahl al-'Uruna fi al-Ukhrati wa lan bihalika amru ba'da masyuratan. Ertinya: Kepala akal itu kesan daripada membawa iman akan Allah iaitu sabar serta membiarkan daripada kejahatan orang akan dia. Dan segala orang yang berbuat kebajikan dalam dunia itu mereka itulah orang yang pilihan dalam akhirat. Dan sekali tiada binasa manusia kemudian daripada saat ...

(The 'aql (thought) is the result of iman (faith) that is patient to vices caused by others. Those who perform good deeds in this world were the selected people in the Yawm alAkhirah).

Seperti sabda Nabi sallā Allāh 'alayhi wa sallam: Ya man 'abdan ha'Allah wa ata' mawaliyah illa adkhuluhu Allah al-Jannah. Ertinya: Barangsiapa hamba yang berbuat bakti ia akan Allah Ta'ala dan akan tuannya, nescaya dimasukkan Allah akan dia syurga.

(UM 41: 543)

(Those who serve Allah and their master will be placed in heaven by Him).

Dan seperti sabda Nabi sallā Allāh 'alayhi wa sallam: Al-Ghiba ashaddu min al-Zina. Ertinya: Yang mengumpat tersangat dosanya daripada zina. ${ }^{26}$

(UM 41: 558)

(Backbiting is of greater sin than adultery)

\section{Conclusion}

Chronologically, Bustan heralds itself as one of the earliest books in the Malay world to cover history, only antedeced by Hikayat Raja Pasai and Sejarah Melayu. Within Bustan itself, al-Raniri utilized universal references which intersected both the primary and secondary historical sources. In terms of sources, it is apparent through his writings that al-Raniri was exposed to different types of Islamic sources during his time. Al-Raniri's basic sources in writing Bustan are the Qur'an and hadith which is evident in the use of 167 of verses from the Qur'an and 216 hadith in Book I-Book IV of Bustan. These references parallel al-Raniri's statement in the introductory part of Bustan, that is to write Bustan using the reference of Qur'an and hadith. ${ }^{27}$ It is a matter of fact that the Qur'an encapsulates within it a large number of narratives appertaining to past nations and the Prophets. These include stories touching upon the creation of the universe, the history of the Prophets and humans on earth as well as the pious saints of Allah. In purposeful effect, these stories clarify the deeds and malefactions of those who came before, and they provide lessons and guidance for human beings that they must abide in accordance to the laws of Allah. Therefore, al-Raniri took stories from the Qur'an as it is the main source of Islamic history. Meanwhile, hadith were used as they are the vital second source of Islam including Islamic history. Pertinently, al-Raniri used hadith not only to strengthen his stories but also to reflect the concept of tawhid in Bustan. Al-Raniri's concept of Islamic history based on the concept of tawhid is manifested in different kinds of references used in writing Bustan especially the Qur'an and hadith.

\footnotetext{
${ }^{26}$ Hadith reported by Ibn Abi Ad-Dunya and Al-Bayhaqi.

${ }^{27}$ Raffles Malay 8 (Bustan al-Salatin), pp. 3-5.
} 


\section{References}

Al-Attas, Syed Muhammad Naquib (1972), Islam dalam Sejarah dan Kebudayaan Melayu, Kuala Lumpur: Penerbit Universiti Kebangsaan Malaysia.

Amirul Hadi (2004), Islam and State in Sumatra, Leiden: Brill Academic Publishers.

Andaya, L. Y. (2001), Aceh's Contribution to Standards of Malayness, Archipel, 61, 29-69.

Arba'iyah Mohd Noor (2002), Ilmu Sejarah dan Pensejarahan, Kuala Lumpur, Malaysia: Dewan Bahasa dan Pustaka.

Azyumardi Azra (2002), Historiografi Islam Kontemporer, Idris Taha (Ed.), Jakarta, Indonesia: Penerbit PT Gramedia Pustaka Utama.

Azyumardi Azra (2004), The Origins of Islamic Reformism in Southeast Asia, Australia: Allen \& Unwin.

Denisova, Tatiana (2011), Refleksi Historiografi Alam Melayu, Kuala Lumpur: Penerbit Universiti Malaya.

Duri, A. A. (1983), The Rise of Historical Writing Among the Arabs, (Lawrence I. Conrad, Trans.), New Jersey, U.S.: Princeton University Press. (Original work published 1960).

Grinter, C. A. (1979), Book IV of the Bustan Us-Salatin by Nuruddin Ar-Raniri: A Study from the Manuscripts of a 17th Century Malay Work Written in North Sumatra, Doctoral dissertation, School of Oriental and African Studies, University of London, United Kingdom.

Jelani Harun (1999), Nuruddin al-Raniri's Bustan al-Salatin: A Universal History and Adab Work from Seventeenth Century Aceh, Doctoral dissertation, London: School of Oriental and African Studies.

Jelani Harun (2008), Bustan al-Salatin (Bab Ketiga) Kisah Raja-Raja Yang Adil, Kuala Lumpur, Malaysia: Dewan Bahasa dan Pustaka.

Jelani Harun (2009), Bustan Al-Salatin: The Garden of Kings: A Malay Mirror for Rulers, Pulau Pinang, Malaysia: Penerbit Universiti Sains Malaysia.

Jones, Russell (2004), Nuru'ddin ar-Raniri Bustanu's-Salatin Bab IV Fasal 1, Kuala Lumpur: Dewan Bahasa dan Pustaka.

Lukmanul Hakim (2017), "Historiografi Islam Melayu-Nusantara: Dari Sejarah Konvensional Menuju Sejarah Total," Turãst: Jurnal Penelitian \& Pengabdian, Vol.5, No. 2, 127-146.

Mahayuddin Haji Yahaya (2009), Sejarah Politik dan Sosiobudaya Masyarakat Islam, Kuala Lumpur, Malaysia: Dewan Bahasa dan Pustaka.

Manuscript Raffles Malay 42 (Bustan al-Salatin)

Manuscript Raffles Malay 8 (Bustan al-Salatin)

Manuscript UM 41 (Bustan al-Salatin)

Muhd. Yusof Ibrahim (2013), Ilmu Sejarah: Falsafah, Pengertian, Kaedah dan Pensejarahan, $2^{\text {nd }}$ Ed., Kuala Lumpur, Malaysia: Dewan Bahasa dan Pustaka.

Muhd. Yusof Ibrahim and Mahayuddin Haji Yahaya (1988), Sejarawan dan Pensejarahan, Kuala Lumpur, Malaysia: Dewan Bahasa dan Pustaka.

Muhidin Mulalić (2012), A Survey of Early Muslim Historiography, Kuala Lumpur: A.S. Noordeen. 
Nisar Ahmed Faruqi (1979), Early Muslim Historiography: A Study of Early Transmitters of Arab History from the Rise of Islam up to the end of Umayyad Period (612-750 A.D.), Delhi, India: Idarah-i Adabiyat-i Delli.

Norhayati Haji Hamzah and Jamaluddin Aziz (2019), "Historical and Didactic Themes in Bustan AlSalatin by Nur Al-Din Al-Raniri: A Study Based on Book I-Book IV," Journal of Al-Tamaddun, Vol. 14, No. 2, 117-142.

Rosenthal, Franz (1968), A History of Muslim Historiography, (2nd ed.), Leiden, Netherlands: E.J. Brill.

Salman, S. and Hakim, L. (2019), "Format Historiografi Islam Nusantara," Tabuah, Vol. 23, No. 1, 5978.

Setia Gumilar (2017), Historiografi Islam: Dari Masa Klasik Hingga Modern, Bandung, Pustaka setia.

Siti Hawa Haji Salleh (Ed.) (1992), Bustan al-Salatin, Kuala Lumpur: Dewan Bahasa dan Pustaka.

T. Iskandar (1966), Bustanu's-salatin, Bab II, fasal 13, Kuala Lumpur: Dewan Bahasa dan Pustaka. 